УДК 330.658 .3

https://doi.org/10.52058/2708-7530-2021-9(15)-51-65

Гой Олесь Тарасович аспірант кафедри управління та бізнесадміністрування, Прикарпатський національний університет імені Василя Стефаника, вул. Шевченка, 57, м. Івано-Франківськ, 76000, тел.: (034) 259-61-57, e-mail: goyoles1995@gmail.com, https://orcid.org/0000-0002-5571-8672

\title{
НАУКОВІ ПІДХОДИ ДО ФОРМУВАННЯ КОРПОРАТИВНОЇ КУЛЬТУРИ В СИСТЕМІ СТРАТЕГІЧНОГО УПРАВЛІННЯ
}

Анотація. Для сучасного суспільства, що розвивається в мінливих умовах, актуальним є пошук дієвих методів стратегічного управління в публічній сфері. Одним із важливих інструментів вирішення проблеми є формування та розвиток корпоративної культури, про що свідчать світовий досвід успішних організацій, які декларують основні норми, засади та правила корпоративної культури, визнаючи іiі провідним чинником розвитку та конкурентоспроможності. Роль чинника корпоративної культури в системі стратегічного управління стає визначальною, коли виникає необхідність формування нової стратегії, та побудови нової системи цінностей. Стан корпоративної культури на вітчизняних підприємствах ще вимагає серйозних досліджень, як зі статистичної точки зору, так і з точки зору основних динамічних змін економіки.

У статті розкрито сутність і поняття «корпоративна культура», зокрема виокремлено економічна, управлінська та соціологічна складова в тлумаченні цього поняття, окреслено різноманітні підходи до іiі визначення. Визначено особливості вітчизняних підходів до дефініції поняття «корпоративна культура». У статті розглянуто основні правила, принципи, інструменти щодо формування корпоративної культури організації задля досягнення сталого розвитку та ефективного функціонування на конкурентоспроможному ринку через систему взаємодії елементів корпоративної культури.

Встановлено, що більшість 3 механізмів корпоративної культури в діяльності організацій практично не використовується, особливо це стосується стратегічного управління в публічній сфері.

Досліджено вплив корпоративної культури на діяльність організації та управління людськими ресурсами, де корпоративна культура в основному розуміється як набір норм, правил, традицій, що приймаються менеджментом $\mathrm{i}$ персоналом організації.

Окреслено ключові функції організацій, що мають міцну корпоративну культуру і в той же час існуючі проблеми впровадження корпоративної культури у діяльність вітчизняних організацій.

Сформульовано чинники, які визначають потребу організацій у зміні 
корпоративної культури, а саме вплив корпоративної культури на показники діяльності та на якість управління. Доведено необхідність формування ефективної корпоративної культури як важливого чинника удосконалення стратегічного управління в публічній сфері.

Ключові слова: корпоративна культура, стратегічне управління, публічне управління, стратегія, місія організації, цінності.

Goy Oles Tarasovych Undergraduate of the Department of Management and Business Administration, Vasyl Stefanyk Precarpathian National University, Shevchenko St., 57, Ivano-Frankivsk, 76000, tel.: (034) 259-61-57, e-mail: goyoles1995@gmail.com, https://orcid.org/0000-0002-5571-8672

\section{SCIENTIFIC APPROACHES TO THE FORMATION OF THE CORPORATE CULTURE IN THE STRATEGIC MANAGEMENT SYSTEM}

Abstract. The search for effective methods of strategic management in the public sphere is relevant for a modern society developing in a dynamic environment. One of the important tools for solving the problem is the formation and development of corporate culture, as evidenced by the world experience of successful organizations that declare the basic standards, principles and rules of corporate culture, recognizing it as a leading factor in development and competitiveness. The role of the corporate culture factor in the system of strategic management is determined by the need for the formation of a new strategy, as well as the initiation of a new system of values.

The state of corporate culture in domestic enterprises will require serious research, both from a statistical and main dynamic changes in the economy points of view. The article reveals the essence and concept of «corporate culture», in particular, it highlights the economic, managerial and sociological components in the interpretation of this concept, defines various approaches to its definition. The features of domestic approaches to the definition of the concept of «corporate culture» are determined. The article considers the basic rules, principles, tools for the formation of corporate culture of an organization to achieve sustainable development and effective functioning in a competitive market through a corporate culture elements interaction system.

It is determined that most of the mechanisms of corporate culture are practically not used in the activities of organizations, especially in the field of strategic management in the public sphere. The influence of corporate culture is investigated on the activities of the organization and human resources management, where corporate culture is mainly understood as a set of standards, rules, traditions adopted by the management and corporate staff. The key functions of organizations with a strong corporate culture and, at the same time, existing problems of introducing corporate culture into the activities of domestic organizations are determined.

The factors that determine the need of organizations to change the corporate culture, namely the influence of corporate culture on performances and on the quality 
of management are formulated. The necessity of forming an effective corporate culture as an important factor in improving strategic management in the public sphere is proved.

Keywords: corporate culture, strategic management, public management, strategy, mission statement, values.

Постановка проблеми. Сучасний розвиток українського суспільства, прагнення України досягти стандартів європейської спільноти заохочують вивчати світовий досвід формування системи стратегічного управління, аналізувати структурні складові позитивного іміджу інституцій державного управління, розробляти власні ефективні моделі відповідно до умов функціонування та національних традицій. Проблеми становлення позитивного іміджу, репутації та перспективи їх формування активно почали досліджуватись в сфері бізнесу, однак у державному управлінні ця проблема залишається актуальною та потребує системного аналізу. Корпоративна культура є досить важливим елементом теорії організації, що в свою чергу підтверджує необхідність розгляду організаційної культури як важливої складової удосконалення системи стратегічного управління в публічній сфері.

Невід'ємною рисою громадянського суспільства $є$ забезпечення відкритості, прозорості та ефективності діяльності владних інституцій. Таке суспільство прямує до децентралізації державної влади, передаючи частину своїх повноважень органам самоуправління, до налагодження взаємодії органів влади з громадськістю на основі узгодження їх позицій, взаємної співпраці та корисності суспільству. Дієвим інструментом досягнення такого взаєморозуміння у суспільстві є зростання його поінформованості та побудова позитивного іміджу владних інституцій, формування якісної системи корпоративної культури.

Впродовж останніх десятиліть зміна ставлення до працівників компаній та корпорацій, нове трактування їх значення в визначенні стратегій розвитку, а також усвідомлення важливості культури, що об'єднує працівників у ефективну команду, надало актуальності та пріоритетності феномену корпоративної культури.

Науковці, які досліджують проблеми виникнення та формування корпоративної культури, стверджують, що вона здійснює потужний вплив на різні сфери діяльності організації, зокрема на визначення стратегії розвитку та ефективність діяльності корпорації як в короткостроковій, так i в довгостроковій перспективі, покращує результативні показники найманих працівників, сприяє зростанню вагомості впровадження мехнізмів системності мотивації фахівців у публічній сфері. Розвиток корпоративної культури необхідно розглядати як обов'язковий інструмент удосконалення соціальноекономічних відносин, що має значний вплив як на підвищення дієвості інструментів стратегічного управління, так i на вдосконалення складових 
ефективної корпоративної культури в публічній сфері загалом.

Аналіз останніх досліджень і публікацій. Сучасні тенденції становлення та розвитку стратегічного управління в публічній сфері вимагають формування фахівців нового типу. Зазначена проблема може бути вирішена завдяки належного організаційно-правового забезпечення, сприятливих соціальноекономічних умов, ефективної кадрової політики та наявності сучасних кваліфікованих, компетентних, моральних, патріотичних, відповідальних, ерудованих, творчих, ініціативних, цілеспрямованих, конкурентоздатних фахівців. Світові успішні компанії цілеспрямовано формують та підтримують комплекс аспектів корпоративної культури через іiі істотний вплив на виробничу та комерційну діяльність, формування активного колективу та покращення показників роботи організації.

Перші спроби наукового аналізу сутності поняття «культура» відомі ще за часів середньовіччя. Вперше запропоновано поняття «культура» римським філософом Марком-Тулій Цицероном, що стосувалось тлумачення філософії як «культури ума». На сьогодні поняття «корпоративна культура» $\epsilon$ в основному проблемою філософського аналізу, оскільки рівень корпоративної культури в організації можна оцінити тільки якісними показниками. Як науковий термін поняття «корпоративна культура» було сформульовано ще в XIX сторіччі німецьким фельдмаршалом Геельмутом Карлом Бернхардом фон Мольтке, який застосував його, надаючи характеристику взаємовідносин в офіцерському середовищі.

Дослідженням сутності поняття корпоративної культури присвятили свої праці такі вчені, як: Бала О., Барановська Л., Бобилєва М., Задихайло Д., Камерон Кім С., Кібенко О., Куінн Роберт Е., Марущак Т., Мерсер Д., Назарова Г., Немченко Т., Палешуцький К., Рухлі Є., Співак А., Хаєт Г., Чайка Г., Чернишова Т., Юрченко В. Сфери впливу корпоративної культури досліджували науковці Й. Кунде Й, Шейн Е, Палеха Ю, Савчук Л., Отенко I, Удальцова М., Ячменьова В. Систематизували основні теоретичні положення корпоративної культури відомі дослідники в сфері менеджменту: Акофф Р., Вілдавський А., Воронкова А., Грінберг Дж., Діл Т. та Кенеді А., Друкер П., Коул Д., Камерон К. та Куінна Р., Погорадзе А., Харісон Р., Хофштед Г., Хенді Ч. та інші.

Проте, незважаючи на теоретичні здобутки у сфері зазначеної проблеми, ми вважаємо, що дослідження сутнісних характеристик має носити системний характер, що у свою чергу сприятиме підвищення якості стратегічного управління та ефективності досягнення прийнятих рішень в сфері публічного управління.

Мета статті - дослідження поняття корпоративної культури та ï складових на основі грунтованого аналізу наукових підходів щодо трактування цього поняття та виявлення його характерних ознак в системі стратегічного управління.

Виклад основного матеріалу. Трансформація національної економіки 
вимагає нового інструментарію стратегічного управління, що має базуватись на знаннях та культурі. Саме поєднання цих двох базових явищ має стати основою розвитку. Система цінностей заснована на отриманому досвіді підкріплені доведеними фактами, що зорієнтована не на технічний потенціал, а на людський, спрятиме ефективнішому менеджменту та усвідомлення цілісності організації, що у свою чергу призведе до досягнення мети.

У менеджменті організації існує така гіпотеза, що організації мають свою культуру, щось за аналогією культури націй. Формування корпоративної культури організації $є$ процесом моделювання та регулювання поведінкових особливостей персоналу на основі тих цінностей, що притаманні організації їх перебування. Іноді пріоритетні цінності організації дещо суперечать цінностям суспільства, оскільки ця гіпотеза сформувалась поступово.

Термін «культура» походить від латинського «cultura», що в перекладі означає догляд, освіта, виховання, розвиток. Духовний розвиток людини, піi здатність до самовдосконалення античні мислителі вважали такою ж важливою складовою, як і розвиток агрокультури або інших промислових сфер суспільства. Зокрема, у науковій літературі під феноменом «культура» розуміють систему цінностей особистості; світогляд особистості; мистецтво спілкування; рівень інтелектуальної, моральної та етичної компетентності фахівця. Відповідно до словника української мови, культура - це сукупність матеріальних і духовних цінностей; освіченість, вихованість [1, с. 395].

Пітер Друкер вважав, що «ми живемо в одному з історичних періодів, які виникають кожні двісті-триста років, коли люди перестають орієнтуватись в оточуючому світі, коли досвіду минулого не достатньо для раціонального пояснення майбутнього» [4, с. 136]. У 1936 р. можна прослідкувати перші згадки наукового поняття «культура підприємства» у працях М. Шерифу, коли він говорив про поняття «соціальні норми». У 60-х роках вченими, об'єктами дослідження яких була організація підприємства, вживаються поняття клімату та культури спілкування на підприємстві. К. Камерон, Р. Куїнн стверджують, що «...успіх компанії визначається цінностями організації, відношенням до ринкових ресурсів, а ніж завоюванням позицій у конкурентній боротьбі; скоріше турботою про розуміння ситуації, ніж проблемами ресурсної переваги. Власне кажучи, навіть важко назвати хоча б одну процвітаючу компанію, яка сприймалася б лідером у своїй справі і не володіла б цілком помітною, що асоціюється тільки 3 нею, організаційною культурою» [6].

У свою чергу, аналізуючи наукову та практичну літературу, поняття «корпоративна культура» науковці тлумачать як переконання фахівця, відповідні норми поведінки, установки і цінності, що визначають як зміст стиль професійної діяльності [8; 12; 13]. Дослідники вважають, що корпоративну культуру слід розглядати як сукупність моделей поведінки, що формуються в процесі адаптації та професійного розвитку людських ресурсів, зміцнює стабільність системи соціальних відносин, актуалізує корпоративну родину, створює атмосферу 
єдності та співпраці, сприяє успішності професійної діяльності. Проведений нами аналіз наукових джерел також дає можливість зазначити, що підгрунтям корпоративної культури $є$ :

- цінності, що визначають моральні принципи фахівців, їх професійну поведінку, правила міжособистісного спілкування;

- місія, що визначає призначення та функціональну роль організації; принципи роботи, що відповідають цінностям організації;

- стратегія розвитку організації як чітко сформульовані перспективи діяльності;

- історія, ритуали і традиції.

Корпоративну культуру в системі стратегічного управління в публічній сфері слід розглядати на основі відповідних характеристик, таких як: особиста ініціатива, ступінь ризику, цілеспрямованість управлінської діяльності, узгодження дій, забезпечення управлінської підтримки, контролю, системи винагород та формування моделі взаємодії. До складових корпоративної культури віднесемо стратегію функціонування та розвитку підприємства, професійне середовище, кадровий ресурс, інновації, імідж та репутацію організації. У роботі Захарчин Г. М. зазначається, що «організаційну культуру ототожнюють із культурою організацій, хоч поняття «організаційна культура» відображає більше ступінь організаційного впорядкування процесу виробництва та системи менеджменту організації, $\epsilon$ важливим елементом культури організації» [17, с. 136].

Мілошевич Н. В. зазначає, що «правильно сформована корпоративна культура (iї ціннісна орієнтація, норма поведінки людей і їх очікування) це свого роду стратегічний інструмент, що дає змогу менеджерам усіх рівнів орієнтувати підрозділи організації, весь промислово-виробничий персонал на реалізацію основної місії підприємства, підвищувати його економічну і соціальну ініціативу, забезпечувати трудову віддачу виробничій справі трудового колективу, полегшувати культуру взаємин на робочих місцях» [11]. Але у цьому випадку метою впровадження корпоративної культури на підприємстві є лише досягнення економічного ефекту, що на нашу думку є обмеженням цього процесу. Одним із завдань залучення до меж корпоративної культури колективу організації має стати підвищення соціальної відповідальності компанії в цілому так і кожного працівника зокрема.

Отож, корпоративна культура це - система відносин між учасниками колективу, що базується на комплексі загальносуспільних норм й правил та власного досвіду організації, використання яких $є$ прийнятним для кожного працівника, що дозволяє оптимально використовувати потенційні можливості системи стратегічного управління, як на iї користь так і суспільства в цілому.

Проаналізувавши праці вчених щодо трактування сутності корпоративної культури ми систематизували зміст та структуру елементів корпоративної культури організації. Метою побудови ефективної системи корпоративної 
культури є формування поведінки персоналу, що сприятиме досягненню цілей організації, базується на чітко визначеній місії компанії, а саме: це його соціальне призначення, тобто те, що суспільство може очікувати від мети ії діяльності [6]. Правильно окреслена місія сприяє вирішенню таких завдань менеджменту як:

- спонукає управлінський персонал систематично здійснювати аналіз сильних і слабких сторін в системі менеджменту з метою пошуку резервів підвищення йог ефективності;

- допомагає об'єднанню працівників у досягненні цілей, кращій взаємодії між керівним складом та підлеглими на різних рівнях ієрархії управління;

- формує позитивний імідж організації.

Задля досягнення мети виділяють такі цілі корпоративної культури: підвищення ефективності діяльності організації через зростання продуктивності праці внаслідок вдосконалення менеджменту персоналу; забезпечення доброзичливої взаємодії співробітників та керівництва та встановлення зворотного зв'язку; формування ставлення персоналу до компанії як до своєї власності 3 почуттям причетності до його справ; підтримка індивідуальної ініціативи та пропозицій працівників; мотивування персоналу до особистого успіху через надання можливостей для власного розвитку; делегування відповідальності; зміцнення корпоративної «родини» (колективу).

Формування мети корпоративної культури та, відповідно до цілей ii досягнення, має базуватись на вихідних засадах, практичних положеннях 3 ефективного управління - принципах корпоративної культури. Бала О. I виділяє такі принципи, як: всеохопленості та системності; відкритості та постійного удосконалення; координації; обов'язковості; вимірності та корисності; індивідуальності; вільного формування; узгодженості та відповідності; чіткості; винагороди; відповідності чинному законодавству [14, с. 13].

$\mathrm{y}$ роботі Вершковського Е. В. наведено такі основні принципи корпоративної культури [3]:

- принцип захисту прав - який вбачає отримання необхідної інформації про корпорацію та формування єдиного корпоративного духу компанії;

- принцип рівності - який забороняе керівництву здійснювати будь-які операції у власних інтересах;

- принцип стратегії - що дозволяє інтегрувати інтереси персоналу та самої організації на довготривалий термін діяльності;

- принцип відкритості - сприяє побудові прозорих відносин, які в свою чергу інтегрують членів колективу в єдине ціле, що формує корпоративні цінності;

- принцип справедливості - дозволяє сформувати належний рівень корпоративного духу і стилю діяльності колективу або організації;

- принцип професіоналізму - сприяє насамперед формуванню взаємодовіри, добробуту, надійності партнерства;

- принцип солідарної відповідальності - сприяє формування корпоративної культури та існуючих в ній норм та цінностей; 
- принцип єдності - передбачає уникнення міжособистісних протиріч у колективі та подвійності у правлінні організацією;

- принцип відповідності - наголошує на достатньому повноваженні співробітника для вирішення завдань та відповідальності за їх виконання;

- принцип цілісності - передбачає цілісність різноманітних структур, що одночасно є самостійними (виробнича, фінансова, соціальна сфери);

- принцип динамічності - передбачає зміну організаційних структур колективу відповідно до життєдіяльності організації (створення, розвиток, функціонування тощо);

- принцип зворотного зв’язку - передбачає обмін інформацією від суб'єкта до об'єкта управління, що надає співвідношення в інформаційній схемі (вхіднавихідна інформація) організації;

- принцип додатковості - який завбачає існування не лише сталих ціннісних впливів, а й стихійного, ймовірного впливу на тенденцію розвитку організації;

- принцип превалювання суспільних інтересів - згідно якого інтереси члена колективу або групи мають бути підпорядковані суспільному інтересу всього колективу або організації;

- принцип єдності - який наголошує на цілісності управління організаційними діями, що мають одну мету;

- принцип стабільності - вбачає здійснення планування у політиці управління щодо зниження плинності членів організації (кадрів);

- принцип ініціативи - згідно якого кожен член організації має самостійність в межах особистої компетенції при прийняття та реалізації певних завдань та рішень.

Потапюк I. П поділяє принципи корпоративної культури на загальні та спеціальні [18]. Кагляк О. О. звертає увагу, що принципи мають бути співвимірні цінностям, саме у такому випадку можливе досягнення цілей підприємства [14]. Вчені, що вивчають проблеми формування корпоративної культури, стверджують, що норми та цінності підприємства мають вплив на різні сфери діяльності. Можна стверджувати, що вони мають бути дотичними до таких питань як: призначення організації (рівень технологій, якість, лідерство у сфері виробництва); влада (повноваження притаманні посаді, повага); повага до людей (турбота про людей та їх потребам, відсутність фаворитизму, повага до індивідуальності, справедливість, мотивування); критерії вибору на керівні посади (власність та ефективність роботи, переваги власних працівників, вплив неформальних відносин та груп); організація роботи та дисципліна (добровільна, примусова, пластичність зміні ролей); стилі керівництва та управління (стилі авторитарний або консультативний або співробітництва, власний приклад, використання цільових груп); процес прийняття рішення (хто приймає рішення, індивідуальне та колективне рішення, необхідність згоди та компроміс); контакти (перевага особистим або письмовим контактам, жорсткість та пластичність службового спілкування; можливість контакту з керівництвом, збори); характер 
соціалізації (спілкування під час та після роботи, чи існують бар'єри, особливі умови спілкування); шляхи вирішення конфліктів (бажання уникнути конфлікту - компроміс, офіційні та неофіційні шляхи, керівництво у вирішенні конфліктних ситуацій); оцінка ефективності роботи (реальна та формальна, відкрита та закрита, результати) $[1 ; 6 ; 7 ; 12 ; 13 ; 15 ; 16 ; 18 ; 22 ; 23]$.

Зовнішній образ (імідж), як складова системи корпоративної культури, став об'єктом дослідження після становлення цього терміну у загальній та соціальній психології в 60-80 роками XX століття. Тогочасний імідж трактувався переважно в контексті теорії сприйняття, діяльності, спілкування і соціального пізнання. Імідж $є$ явищем, що використовується для презентування у суспільних відношеннях того чи іншого типу групової поведінки. 3 іншого боку, роз'яснювалось впровадження технологій, що дозволяли формувати поведінку як груп в цілому так і суб'єктів зокрема.

Зовнішній образ іміджу організації відслідковуються в символах, що справляють емоційний вплив на споживачів i можуть бути ефективним мотиваційним чинником для співробітників, оскільки виражають певну елітарність їх у стосунках із середовищем i диктують певну корпоративну поведінку. Як елемент системи корпоративної культури - це манера поведінки групи, яка представляє організацію, іiї мова, правила, зафіксовані у письмовому вигляді, а також розміри організації, технологія, продуктивність, фірмовий та товарні знаки, місце на ринку, фірмовий одяг, будівлі тощо [13, с. 136] .

Ми вважаємо, що зовнішній образ організації з одного боку є елементом системи корпоративної культури, а з іншого - є наслідком іiї впровадження. Варто зазначити, що зовнішній образ (імідж) та цінності корпоративної культури проявляються на різних рівнях структури культури організації. А саме: зовнішній образ виявляється у прояві культури організації внаслідок контакту 3 ii представниками на рівні поверхневому (символьної) культури організації. Відповідно цінності проявляються на так званому смисловому рівні (або рівень норм і цінностей).

Ми поділяємо типологію, що пропонується Шейном Е. [22], яку у свою чергу Хенді Ч. [19] пояснив на міфології древньої Греції:

1. «Культура влади», яку уособлює головний Бог (Зевс). У цій культурі ключова особа - лідер, його особисті якості і здібності. Управлінці, які підтримують такий тип корпоративної культури вирізняються високим рівнем емпатії, завдяки чому досягається швидкість прийняття рішень. Вони мислять швидше інтуїтивно ніж логічно. Їхній розвиток відбувається на власних помилках. В цій культурі цінуються контроль за ресурсами та особиста харизма.

2. «Рольова культура», яку уособлює Бог логіки і розуму (Аполлон) характеризується суворим функціональним розподілом ролей за спеціалізацією учасників. Основним джерелом влади $є$ не особисті якості, а становище в ієрархічній структурі. 
3. «Культура завдання», яку уособлює Богиня мудрості (Афіна). Тип культури орієнтований, на вирішення завдань, реалізацію проектів. Люди розглядаються не як особистості, а як ресурсний потенціал, який організація може використати в даний момент для вирішення проблем в певних сферах. Ефективність діяльності компаній 3 такою культурою визначається високим професіоналізмом співробітників і кооперативним груповим ефектом.

4. «Культура особистості», яку уособлює егоїстичний Бог виноробства (Діоніс). Підприємство з цим типом культури об'єднує людей для того, щоб вони могли домагатися власних цілей. Цей тип культури є ефективним для досягнення цілей тоді, коли талант і навики окремих особистостей мають вирішальне значення для організації.

Сприйняття корпоративної культури всередині організації має певні рівні. Едгар Шейн пропонує розглядати багаторівневу структуру корпоративної культури, в якій нараховує три рівні - «поверхневий» або символічний, «підповерхневий», глибинний [22]. У працях вчених можна прослідкувати ще один рівень, який найчастіше називають «внутрішнім». Це прояв неписаного кодексу правил, який діє серед членів організації і впливає як на їхні відносини так і на зовнішнє середовище підприємства. На нашу думку, він $є$ запорукою існування третього рівня, глибинних переконань, що формуються протягом тривалого періоду як існування організації так і життя суб'єкта організації. Саме на цьому рівні і має відбуватись ранжування цілей, у якому буде проявлятись відповідальність як перед працівниками та підприємством, але й суспільством.

Будь-яка ідентифікація принципів, на нашу думку, має бути націлена на те, щоб більш грунтовно формувати завдання корпоративної культури за окремими напрямками - управління персоналом, управління ефективністю діяльності організації, у тому числі стратегічній перспективі, формування позитивного іміджу. Цінності, на яких базується корпоративна культура, є «постулатом», який $\epsilon$ основою правил поведінки кожного працівника. Шейн Е. зазначає, що цінності - центральний елемент корпоративної культури, що визначає специфіку всіх інших моментів «людського аспекту» організації: індивідуальних і групових інтересів, міжособистісних і групових відносин, мотивації [22]. На основі системи цінностей формуються організаційні норми, які виступають як регулятори службового поводження. Вони припускають санкціонування поводження на основі ряду оцінних критеріїв. В організаційній культурі норми як правило закріплені у вигляді своєрідного кодексу правил поведінки, стандартів якості й обслуговування, системи обрядів та церемоній [22].

У свою чергу на формування корпоративної культури в публічній сфері впливають відповідні чинники, які слід згрупувати на зовнішні та внутрішні. До зовнішніх віднесемо глобалізаційні процеси; соціально-політичне становище у суспільстві; нормативно-правове забезпечення стратегічного управління; ринок затребуваності фахівців; місцезнаходження; наявність стратегічного плану діяльності; рівень підготовки фахівців; рівень заробітної плати; тощо. До 
внутрішніх - специфічні особливості публічних інституцій; матеріально-технічне забезпечення; час існування організації; рівень професійної компетентності фахівців; морально-психологічний клімат у колективі; мотиваційний компонент; статус фахівця у професійному середовищі; плинність кадрів; керівник і стиль управління; прийнята система лідерства; комунікативна взаємодія; стилі вирішення конфліктів у колективі; прийняття символіки, традицій та звичаїв колективу.

Науковці виокремили основні етапи управлінського процесу щодо розвитку корпоративної культури:

- аналіз діючої культури ( цінності, традиції і символіка, стандарти поведінки, авторитети організації, існуючі методи формування i розвитку корпоративної культури);

- розробка корпоративного кодексу (визначення місії, стратегічних перспектив і пріоритетних напрямків розвитку, визначення загальних правил поведінки, традицій і символіки);

- визначення форм і методів роботи з персоналом;

- реалізація проектів;

- аналіз динаміки становлення корпоративної культури організації (на основі загальних критеріїв інтересів).

Зауважимо, що вище зазначене забезпечить ідентифікацію фахівцяуправлінця з організацією та усвідомлення власної причетності до формування корпоративних цінностей. Разом з тим, до основних форм, методів і методик формування ефективної корпоративної культури слід віднести:

- розробку системи цінностей, цілей і конкретних завдань щодо їх реалізації;

- розробку системи пошуку, обслуговування і «утримання» клієнтів;

- розробку програми взаємодії з публічними інституціями;

- інформаційне забезпечення.

Також науковці й практики виділяють відповідні функції корпоративної культури, зокрема: оціночно-нормативну; законовідповідальну; регулюючу; динаміко-змінну; пізнавальну; творчо пошукову; комунікаційну; мотивуючу; змістоутворюючу (вплив на світогляд); звітно-контролюючу; суспільної пам'яті; професіонально-змістовну; інноваційно зобов'язуючу; галузево-відповідальну $[8 ; 12 ; 13]$. Не викликає жодних сумнівів доцільність реалізації вищезазначених функцій як основи забезпечення формування ефективної корпоративної культури.

На основі аналізу та специфіки стратегічного управління в публічній сфері доцільно виокремити компоненти корпоративної культури, до яких віднесемо: прийняття системи лідерства;

- стилі вирішення конфліктів;

- моделі прийняття рішень;

- систему комунікативної взаємодії;

- статус фахівця у професійному середовищі; 
- професійну взаємодію та взаємозв'язки;

- прийняття символіки, традицій та звичаїв колективу,

- кар'єрний ріст,

- високий рівень комунікативної взаємодії у колективі,

- володіння фахівцями інструментами тайм-менеджменту,

- організацію сприятливого професійного середовища,

- процес професійного розвитку кожного фахівця колективу,

- дотримання професійної етики та методи іiі стимулювання, дотримання дрес-коду, символіки організації [8].

Пріоритетного значення у процесі формування корпоративної культури фахівців публічної сфери слід відвести позитивній професійній культурі. Ця важлива категорія $є$ основою професійної діяльності й взаємодії у професійному середовищі, здатності реагувати та адаптуватись до зовнішніх і внутрішніх змін, підгрунтям успішної репутації організації.

Висновки. Корпоративна культура виступає дієвим та ефективним комплексом складових елементів процесу прийняття управлінських рішень в публічній сфері, що базується на суспільних та набутих досвідом цінностях демократичного суспільства. Системне дослідження цього питання сприятиме підвищенню ефективності стратегічного управління в публічній сфері. Високий рівень корпоративної культури $\epsilon$ важливим стратегічним чинником, який мобілізує всі структурні ланки колективу задля досягнення поставлених цілей в рамках задекларованої місії організації. Тому на сьогодні вивчення та аналіз наукових підходів до формування корпоративної культури є важливим чинником досягнення успіху в організаціях.

\section{Лimepamypa:}

1. Білодід І.К. Словник української мови : у 11 т. / І.К. Білодід, А.А. Бурячок. - К. : Наук. думка, 1979. - Т. 4. -839 с.

2. Бала О.І. Корпоративна культура - чинник соціально-економічного розвитку організації / О.І. Бала // Вісник Нац. ун-ту «Львівська політехніка». - 2006. - № 567: Менеджмент та підприємництво в Україні: етапи становлення і проблеми розвитку. - С. 6-11.

3. Вершковский Э.В. Режиссура массовых клубных представлений / Э.В. Вершковский. - Л. : ЛДИКМ, 1981. -72 с.

4. Друкер П.Ф. Практика менеджмента / П.Ф. Друкер. - СПб. : Изд. дом «Вильямс», 2002. $-258 \mathrm{c}$.

5. Задихайло Д.В. Корпоративне управління : навч. пос. / Д.В. Задихайло, О.Р. Кібенко, Г.В. Назарова. - Х. : Еспада, 2003. - 688 с.

6. Камерон К.С. Диагностика и изменение организационной культуры / К.С. Камерон, Р.Э. Куинн. - СПб : Питер, 2001. - 320 с.

7. Кунде Й. Корпоративная религия. Создание сильной компании с яркой индивидуальностью и корпоративной душой / Й. Кунде. - СПб. : Стокгольмская школа экономики, 2004. $-267 \mathrm{c}$.

8. Марущак Т. Корпоративная культура предприятий сферы услуг / Т. Марущак // Персонал. - 2001. - № 6. - С. 37-39.

9. Мацокін А. Корпоративна культура \& державна служба. Ціннісні орієнтири / 
А. Мацокін // Держслужбовець, 2018. - № 11. Режим доступу :

https://i.factor.ua/ukr/journals/ds/2018/november/issue-11/article- 40649.html

10. Мерсер Д. ИБМ : Управление в самой преуспевающей корпорации мира / Д. Мерсер. - М. : Прогресс, 1991. - 456 с.

11. Мілошевич Н.В. Корпоративна культура управління як фактор підвищення результативності діяльності підприємства / Н.В. Мілошевич // Галицький економічний вісник. - Т. : ТНТУ, 2017. - Т. 52. - № 1. - С. 44-51.

12. Отенко О.П. Корпоративна культура: міжнародний та трансформаційний аспекти : монографія / І.П. Отенко, М.І. Чепелюк. - Х. : ХНЕУ ім. С. Кузнеця, 2018. - 243 с.

13. Палеха Ю.І. Ключі до успіху або Організаційна та управлінська культури / Ю.І. Палеха. - К. : Вид-во Європ. ун-ту фінансів, інформ. систем, 2000. - 337 с.

14. Бала О.І. Принципи корпоративної культури підприємств: сутність та види / О.І. Бала, Р.Д. Бала, О.В. Мукан // Вісник Нац. ун-ту «Львівська політехніка». - 2010. - № 682: Менеджмент та підприємництво в Україні: етапи становлення і проблеми розвитку. - С.11-15.

15. Савчук Л.М. Функції соціального партнерства / Л.М. Савчук // Науковий вісник УМО. Економіка та управління. - 2016. - № 2. Режим доступу: http://nbuv.gov.ua/UJRN/nvumo_2016_2_12.

16. Спивак В.А. Корпоративная культура / В.А. Спивак. - СПб. : Питер, 2001. - 352 с.

17. Степико М.Т. Буття етносу: витоки, сучасність, перспективи (філософськометодологічний аналіз) / М.Т. Степико. - К. : Знання. - 1998. -251 с.

18. У Уальцова М.В. Социология управления / М.В. Удальцова. - М. : ИНФРА-М, 1998. $-320 \mathrm{c}$.

19. Хэнди Ч. По ту сторону уверености. О новом мире внутри и вокруг организации / Ч. Хэнди. - СПб. : Питер, 2002. - 224 с.

20. Чайка Г.П. Культура ділового спілкування менеджера / Г.П. Чайка. - К. : Знання, 2005. - 442 c.

21. Чернишова Т.О. Деякі аспекти корпоративної культури організації / Т.О. Чернишова, Т.А. Немченко // Наукові праці КНТУ. Економічні науки. - 2010. - Вип. 17. - С. 328-330.

22. Шейн Э. Организационная культура и лидерство / Э. Шейн. -СПб. : Питер, 2002. - 328 с.

23. Ячменьова В.М. Корпоративна культура промислового підприємства: формування та розподіл витрат : монографія / В.М. Ячменьова, Н.В. Царенко. - Сімферополь : Аріал, 2011. - 206 с.

24. Kirilova Filipova, M. Relationship between corporate culture and competitive power of the companies in the tourism industry / M. Kirilova Filipova // Tourism \& Management Studies. 2015. - № 11(1). - P. 98-103.

25. Rühl E. Unternehmengskultur - Konzepte und Methoden. Kulturmanagement in schweizarischen Industrieunternehmungen. - Bern : Haupt Verlag. - 1991. - 234 p.

\section{References:}

1. Bilodid, I.K. (1979). Slovnyk ukrains'koi movy [Dictionary of the Ukrainian language]. Kyiv, Ukraine : Naukova dumka. [in Ukrainian]

2. Bala, O.I. (2006). Korporatyvna kultura - chynnyk sotsialno-ekonomichnoho rozvytku orhanizatsii [Corporate culture - a factor of socioeconomic development of an organization]. Visnyk Natl. Univ. "Lvivska politekhnika": Menedzhment ta pidpryiemnytstvo v Ukraini: etapy stanovlennia $i$ problemy rozvytku, 567, 6-11 [in Ukrainian].

3. Vershkovskiy, E.V. (1981). Rezhissura massovykh klubnykh predstavleniy [Directing mass club performances]. Leningrad, Russia: LDIKM [in Ukrainian].

4. Druker, P.F. (2002). Praktika menedzhmenta [Management Practice]. Moskva, Russia: Izd. dom "Víl'yams. [in Russian]. 
5. Zadykhaylo, D.V. (2003). Korporatyvne upravlinnya [Corporate Governance]. Kharkiv, Ukraine: Espada.

6. Kameron, K.S. \& Quinn, R.E. (2001). Diagnostika i izmeneniye organizatsionnoy kul'tury [Diagnostics and Change in Organizational Culture]. Saint-Petersburg, Russia: Piter. [in Russian].

7. Kunde, Y. (2004). Korporativnaya religiya. Sozdaniye sil'noy kompanii s yarkoy individual'nost'yu i korporativnoy dushoy [Corporate Religion. Creating a strong company with a vibrant personality and corporate soul]. Saint-Petersburg, Russia: Stokgol'mskaya shkola ekonomiki. [in Russian].

8. Marushchak, T. (2001). Korporativnaya kul'tura predpriyatij sfery uslug [Corporate Culture of Service Enterprises]. Personal, 6, 37-39. [in Ukrainian].

9. Matsokin, A. (2018). Korporatyvna kultura \& derzhavna sluzhba. Tsinnisni oriientyry [Corporate Culture \& Civil Service. Value Guidelines]. Derzhsluzhbovets', 11, available at: https://i.factor.ua/ukr/journals/ds/2018/november/issue-11/article-40649.html. [in Ukrainian].

10. Merser, D. (1991). IBM : Upravleniye v samoy preuspevayushchey korporatsii mira [IBM: Management in the world's most successful corporation]. Moscow, Russia: Progress. [in Russian].

11. Milosevich, N.V. (2017). Korporatyvna kultura upravlinnia yak faktor pidvyshchennia rezultatyvnosti diialnosti pidpryiemstva [Corporate management culture as a factor in improving the performance of an enterprise]. Halyts'kyy ekonomichnyy visnyk, 52(1), 44-51. [in Ukrainian].

12. Otenko, O.P. \& Chepelyuk, M.I. (2018). Korporatyvna kul'tura: mizhnarodnyy ta transformatsiynyy aspekty [Corporate Culture: International and Transformational Aspects]. Kharkiv, Ukraine: KHNEU im. S. Kuznetsya. [in Ukrainian].

13. Palekha, Yu.I. (2000). Klyuchi do uspikhu abo orhanizatsiyna ta upravlins'ka kul'tury [Keys to success or organizational and managerial culture]. Kiev, Ukraine: Vydav. Yevrop. univ. finansiv, inform. system. [in Ukrainian].

14. Bala, O.I., Bala, R.D. \& Mukan, O.V. (2010). [Principles of corporate enterprise culture: essence and types]. Visnyk Natl. Univ. «L'vivs'ka politekhnika»: Menedzhment ta pidpryyemnytstvo $v$ Ukrayini: etapy stanovlennya i problemy rozvytku, 682, 11-15. [in Ukrainian].

15. Savchuk, L.M. (2016). [Functions of social partnership]. Naukovyy visnyk UMO. Ekonomika ta upravlinnya, 2, available at: http://nbuv.gov.ua/UJRN/nvumo_2016_2_12.

16. Spivak, V.A. (2001). Korporativnaya kul'tura [Corporate Culture]. Saint-Petersburg, Russia: Piter. [in Russian].

17. Stepyko, M.T. (1998). Buttya etnosu: vytoky, suchasnist', perspektyvy (filosofs'kometodolohichnyy analiz) [Being of Ethnos: Origins, Present, Perspectives (Philosophical and Methodological Analysis)].Kiev, Ukraine: Tovarystvo "Znannya". [in Ukrainian].

18. Udal'tsova, M.V. (1998). Sotsiologiya upravleniya [Sociology of Management]. Moscow, Russia: INFRA. [in Russian].

19. Khendi, Ch. (2002). Po tu storonu uverenosti. O novom mire vnutri i vokrug organizatsii [Beyond Confidence. About the new world in and around the organization]. Saint-Petersburg, Russia: Piter. [in Russian]

20. Chayka, H.P. (2005). Kul'tura dilovoho spilkuvannya menedzhera [Managerial Business Communication Culture]. Kiev, Ukraine: Znannya. [in Ukrainian].

21. Chernyshov, T.O. \& Nemchenko, T.A. (2010). Deiaki aspekty korporatyvnoi kultury orhanizatsii [Some aspects of corporate culture of an organization]. Naukovi pratsi KNTU. Ekonomichni nauky, 17, 328-330. [in Ukrainian].

22. Shein, E. (2002). Organizatsionnaya kul'tura i liderstvo [Organizational Culture and Leadership]. Saint-Petersburg, Russia: Piter. [in Russian]

23. Yachmeniova, V.M. \& Tsarenko N.V. (2011). Korporatyvna kul'tura promyslovoho pidpryyemstva: formuvannya ta rozpodil vytrat [Corporate culture of industrial enterprise: formation and distribution of costs]. Simferopol, Ukraine: Arial. [in Ukrainian]. 
24. Kirilova Filipova, M. (2015). Relationship between corporate culture and competitive power of the companies in the tourism industry. Tourism \& Management Studies, 11(1), 98-103.

25. Rühli, E. (1991). Unternehmengskultur - Konzepte und Methoden. Kulturmanagement in schweizarischen Industrieunternehmungen. Bern, Switzerland: Haupt Verlag. 